\title{
中国沿海省区海洋绿色发展测度及影响机理
}

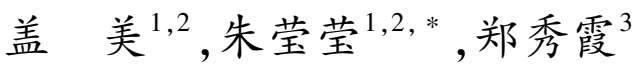 \\ 1 教育部人文社科重点研究基地, 海洋经济与可持续发展研究中心, 大连 116029 \\ 2 辽宁师范大学海洋可持续发展研究院, 大连 116029 \\ 3 辽宁师范大学附属职业中专,大连 116029
}

\begin{abstract}
摘要:海洋绿色发展是海洋高质量发展的重要内容,坚持生态优先和资源可持续的绿色发展模式对于海洋可持续的意义重大。 在梳理了海洋绿色发展概念与内涵基础上, 以沿海 11 省市为研究对象,基于 2006-2017 年沿海各省市的面板数据,建立海洋 绿色发展评价指标体系, 通过可变模糊识别模型对海洋绿色发展水平进行测度,并运用 Arcgis 软件和马尔可夫空间模型对其进 行时空演变分析,最后运用面板数据模型进行影响因素分析。结果表明: (1)2006-2017 年我国海洋绿色发展水平一直保持增 长趋势, 总体提高了 $19.6 \%$, 但整体仍呈中等水平,且地区差异明显。在空间分布上,空间集聚特征依然明显,东南沿海地区总 体海洋绿色发展水平相对较高,西南和东北部分地区海洋绿色发展水平相对较低。(2)从时空演化特征来看,上海、天津、山东的 海洋绿色发展水平相对较高, 河北、广西的海洋绿色发展水平相对较低。区域背景对海洋绿色发展类型转移具有显著影响, 高 水平区域背景对海洋绿色发展水平增长具有辐射、促进作用,而低水平区域背景对增长具有制约、减缓作用。(3从外部因素来 看,政府调控、陆域经济水平和开放程度对海洋绿色发展有正向显著影响,环境治理有负向显著影响; 从内部因素来看,海洋产 业结构、海洋管理和海洋资源利用都有正向显著影响。根据总结以上结论,针对不同地区的海洋绿色发展情况提出不同的发展 途径与对策,为海洋绿色发展提供科学的参考依据。
\end{abstract}

关键词: 海洋绿色发展;评价指标体系; 可变模糊识别模型;时空演化;影响因素

\section{Marine green and its influence mechanism of coastal cities}

GAI Mei ${ }^{1,2}$, ZHU Yingying ${ }^{1,2, *}$, ZHENG Xiuxia ${ }^{3}$

1 Key Research Base of Humanities and Social Sciences of the Ministry of Education, Center for Studies of Marine Economy and Sustainable Development, Liaoning Normal University, Dalian 116029, China

2 Institute of Marine Sustainable Development, Liaoning Normal University, Dalian 116029, China

3 The Vocational School Attached to Liaoning Normal University, Dalian 116029, China

\begin{abstract}
Marine green development is an important part of marine high-quality development. Adhering to the green development mode of ecological priority and resource sustainability is of great significance for marine sustainable development. On the basis of combing the concept and connotation of marine green development, taking 11 coastal provinces and cities as the research object, based on the panel data of coastal provinces and cities from 2006 to 2017 , the evaluation index system of marine green development level was established and the level of marine green development was measured by variable modulus and identification model, then use the ArcGIS software and the Markov space model to analyze its spatiotemporal evolution. Finally, use the panel data model to analyze the influencing factors. The study results show that from 2006 to 2017, the level of marine green development in China has maintained an increasing trend and the overall increase is $19.6 \%$, but the overall is still keep the medium level, and have obviously regional differences. In terms of
\end{abstract}

基金项目:国家环境保护海洋生态环境整治修复重点实验室基金资助(202105)

收稿日期:2020-10-06; 网络出版日期:2021-07-26

*通讯作者 Corresponding author.E-mail: zyy17862326551@163.com 
spatial distribution, the characteristics of spatial agglomeration are still obvious. For example, the overall level of marine green development in southeast coastal areas is relatively high, while the level of marine green development in southwest and northeast areas is relatively low. According to the distribution at provincial scale, the level of marine green development in Shanghai, Tianjin and Shandong is relatively high, and the level of marine green development in Hebei and Guangxi is relatively low. The regional background has a significant impact on the transfer of marine green development types, that is, when regions are surrounded by high-level regions, there is radiated, promoting influence on the growth of marine green development level, and when regions are surrounded by low-level regional, there is constrained influence on the growth of marine green development level. From the perspective of external factors, government regulation, land economy level and open degree have positive and significant impacts on the green development of the ocean, the environmental governance has negative and significant impact on the green development of the ocean, and marine industry structure, marine management and marine resources utilization all have positive and significant influence on the green development of the ocean. According to the above conclusions, the paper puts forward different development approaches and countermeasures for marine green development in different regions, which provides scientific reference for marine green development.

Key Words : Marine Green Development; Evaluation Index System; spatio-temporal evolution; influencing factors; variable fuzzy recognition model

党的十八届五中全会上, 习近平提出将“绿色” 发展作为核心发展理念, 指出“人与自然和谐共处为价值 取向,绿色低碳循环利用为主要原则,生态文明建设为基本抓手”。截至 2019 年海洋的生产总值达到 8.9 万 亿元, 占生产总值的 $9.1 \%{ }^{[1]}$, 由此可见,我国海洋发展的前景广阔。但由于早期海洋经济的粗放增长,海洋生 态问题愈发严重 ${ }^{[2]}$, 因此海洋绿色发展成为了海洋发展的必然趋势, 厘清海洋绿色发展的时空动态演变规律 和影响机理,为海洋经济高质量发展提供了借鉴。

1989 年首次提到以环境保护为核心的绿色发展概念是在《绿色经济蓝图》一书中 ${ }^{[3]}$ 。随着对绿色发展理 念的认识加深,2011 年 UNEP (联合国环境规划部) 关于绿色经济报告中指出: “绿色发展需要经济的高效发 展和公平, 确保在经济在向低碳过渡时, 资源高效, 具有社会包容性” ${ }^{[4]}$ 。胡鞍钢等认为绿色发展是以经济、 社会、生态为一体, 以绿色创新为主要途径, 以绿色财富增长和人类绿色福利增加为目标, 从而达到共同和谐 的最终目标 ${ }^{[5]}$ 。黄跃等认为绿色发展是在资源环境容量约束下, 实现经济、社会、生态协调发展以及综合利 益的最大化 ${ }^{[6]}$ 。在海洋层面上, 周峰认为, 实现海洋绿色发展需要加强陆海统筹、依法治海、发展绿色经济、 协调区域海洋部门管理以及培养国民海洋文化意识, 最终实现海洋可持续发展 ${ }^{[7]}$ 。相关海洋绿色发展的研 究还太少, 关于海洋绿色发展的定义也还未成熟, 因此, 在借鉴以往学者的基础上, 本文将海洋绿色发展定义 为: 在海洋可持续发展和海洋生态文明指导下, 以海洋经济绿色发展、海洋生态环境友好、海洋资源合理利用 及海洋文化与管理制度不断完善为目标, 从而实现海洋绿色发展, 实现人与海和谐共生。

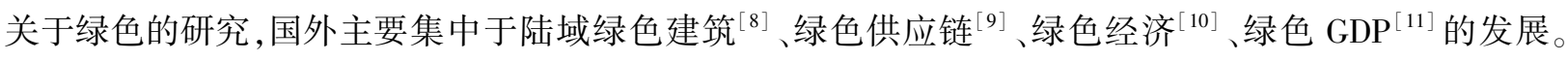
而关于绿色发展的研究较少, 如: 绿色发展增长绩效方面, Li K 等用绿色发展增长绩效( GDGI) 衡量可持续发 展随时间的变化 ${ }^{[12]}$ 。Chao Feng 等从全球视角使用数据包络分析绿色发展绩效指数 ${ }^{[13]}$; 时空分析方面, Caizhi S 等 ${ }^{[14]}$ 和 Zhou $\mathrm{B}^{[15]}$ 等分别利用耗散结构理论和 GIS 空间分析技术研究绿色发展时空演变的趋势和规 律; 影响因素方面, Hasan Rüstemoğlu 运用 LMDI 模型研究绿色发展的环境影响机制 ${ }^{[16]}$ 。国际上目前关于海 洋绿色发展的研究还没有涉及, 但是关于港口、海洋旅游等的微观层面研究比较全面 ${ }^{[17-18]}$ 。国内绿色发展的 论文也集中在内陆, 如: 张欢等从美丽家园、生产消费、高端发展三个方面构建了绿色发展指标体系 ${ }^{[19]}$, 孙才 志等基于信息熵模型和耗散结构模型评价绿色发展 ${ }^{[20]}$; 李俊杰等 ${ }^{[21]}$ 、郭永杰 ${ }^{[22]}$ 等分别探究了中原城市群和 宁夏的绿色发展时空分异特征; 程钰等对中国 30 个省市绿色发展影响机制展开研究 ${ }^{[23]}$, 杜建国等指出智慧 城市建设对城市绿色发展有促进作用 ${ }^{[24]}$ 。海洋绿色的研究, 主要集中于海洋生态文明建设、海洋绿色经济发 
展和海洋绿色经济效率, 如: (1)孙剑锋等对沿海城市生态文明建设水平进行分析 ${ }^{[25]}$, 苗德霞等 ${ }^{[26]}$ 、田良等 ${ }^{[27]}$ 分别对江苏、山东的海洋生态文明建设进行了探究; 2)张莉等评价广东海洋经济绿色发展效益 ${ }^{[28]}$, 贾建琦等 分析了我国海洋经济绿色包容性水平的时空演变格局和海洋经济绿色的驱动因素 ${ }^{[29]}$; 3)赵昕采用投影寻踪 法测算了沿海 11 省市的海洋绿色经济效率以及时空演变特征 ${ }^{[30]}$, 关洪军等使用 DEA-Malmquist 指数模型测 算海洋经济绿色全要素生产率, 并分析其时空演化特征 ${ }^{[31]}$, 丁黎黎等构建了 "资源与环境损耗指数" 测算海 洋经济绿色全要素生产率 ${ }^{[32]}$ 。

通过国内外研究的总结发现: (1)关于海洋绿色发展的研究目前涉及的较少, 而海洋作为未来发展的关键, 关于海洋可持续发展的研究需要不断深化。(2)关于海洋绿色发展的定义未成熟,科学合理的海洋绿色发展评 价体系还未形成, 缺乏统一规范的评价指标。(3)关于沿海城市海洋绿色发展水平的测度、时空演变和影响海 洋绿色发展水平的因素等需要进一步探究。本文在前人的研究基础上,进行补充: (1)首次提出海洋绿色发展 定义, 将陆地的绿色发展测度、影响机理及调控相关研究延伸到海洋, 既加深了对该领域理论与实际的研究, 又拓宽了理论的研究广度和应用范围。(2)在指标体系的构建上, 从海洋经济绿色发展、海洋生态环境友好、海 洋资源利用程度和海洋文化管理建设 4 个方面构建海洋绿色发展指标体系,使绿色发展评价体系更全面更合 理。(3)研究方法方面, 本文首次将可变模糊识别模型应用于海洋绿色发展水平测度,可变模糊识别理论与方 法与以往的评价方法不同, 它是在基本模型的基础上通过变换参数变化成多个模型进行评价, 提高了评价结 果的可信度。再运用空间马尔可夫转移模型对区域海洋绿色发展的动态时空演变规律进行研究,为区域间协 调发展提供了参考依据。

\section{1 海洋绿色发展水平研究机理、评价指标构建和数据来源}

\section{1 海洋绿色发展水平研究机理}

由于海洋生态破坏、海洋管理不足等海洋问题的出现, 人海关系开始紧张,海洋绿色发展要处理好海洋发 展、海洋生态和人之间的关系, 从而达到海洋可持续发展、人与海和谐共生。本文通过梳理已有研究文献并结 合海洋发展特点, 认为海洋绿色发展是在新时代背景下, 以海洋生态文明建设理念为指导, 从海洋经济增长、 生态环境、资源利用和文化管理四个子系统出发构建海洋绿色发展水平评价体系(图 1)。海洋绿色发展水平 和四个子系统相互作用, 其中海洋经济增长在支持海洋绿色发展的基础上也被海洋绿色发展水平所抑制, 经 济发展低排放、产业结构合理性和经济质量的高效性都是判定海洋经济绿色发展的依据; 生态环境响应海洋

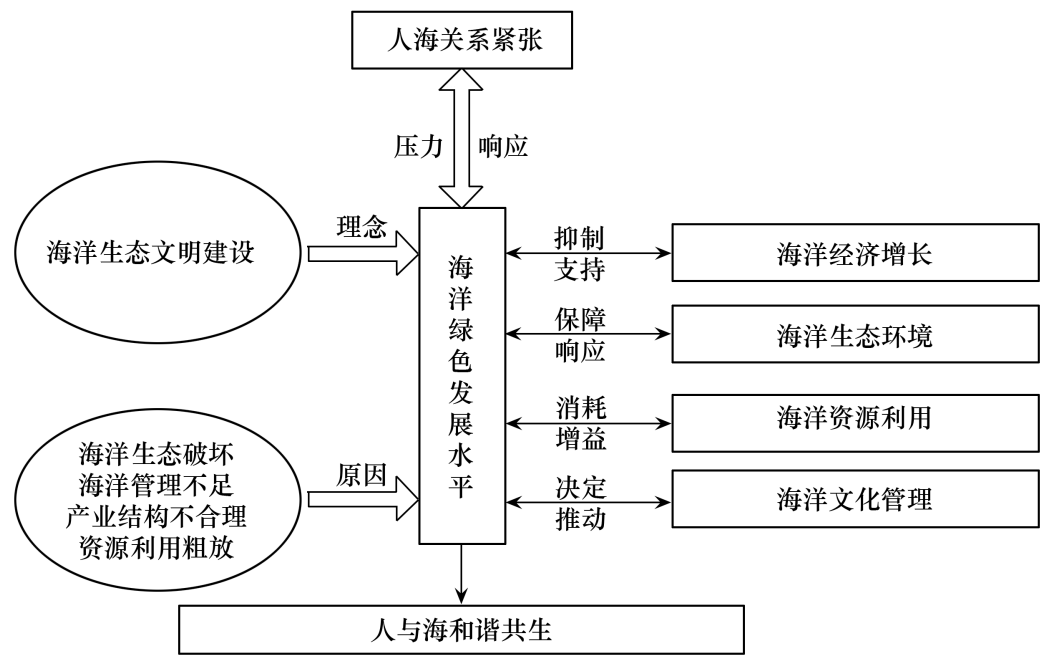

图 1 海洋绿色发展作用机理

Fig.1 Mechanism of Marine Green 
绿色发展,海洋绿色发展保障海洋生态环境健康;海洋资源主要包括空间资源、化学资源、生物资源和旅游资 源, 有效利用海洋资源能增益海洋绿色发展水平;海洋文化管理对于海洋绿色发展起到推动作用,海洋文化是 人类关于海洋的一切精神成果和物质成果,海洋绿色发展决定了海洋文化水平和海洋管理程度。

\section{2 指标体系的构建}

本文依照对于海洋绿色发展的定义, 分别从海洋经济绿色发展、海洋生态环境友好、海洋资源利用程度、 海洋文化管理建设四个一级指标,多个层面评价海洋的绿色发展,更好的测度海洋绿色发展水平。在二级指 标的构建方面, 在海洋经济绿色发展方面, 不仅要考虑海洋经济的增长质量, 还需要减少海洋经济增长带来的 能源消耗, 产业结构合理性也是决定海洋经济绿色发展的重要条件。对于海洋生态环境保护, 需要兼顾海洋 环境保护和海洋生态健康,忽视其中哪一项都无法更好测度海洋生态环境的绿色化。从海洋的空间资源、化 学资源、生物资源和旅游资源四个角度全面测度海洋资源的利用程度, 并且采用了定性指标海洋旅游吸引力 来评价海洋旅游资源。海洋文化管理建设指标中使用了海洋文化宣传力度和海洋制度体系完善度两个定性 指标, 定性和定量指标结合, 从主观和客观两个层面来评价海洋文化建设和行政管理,使得评价结果更加具有 合理性。具体评价指标体系如 (图 2)。

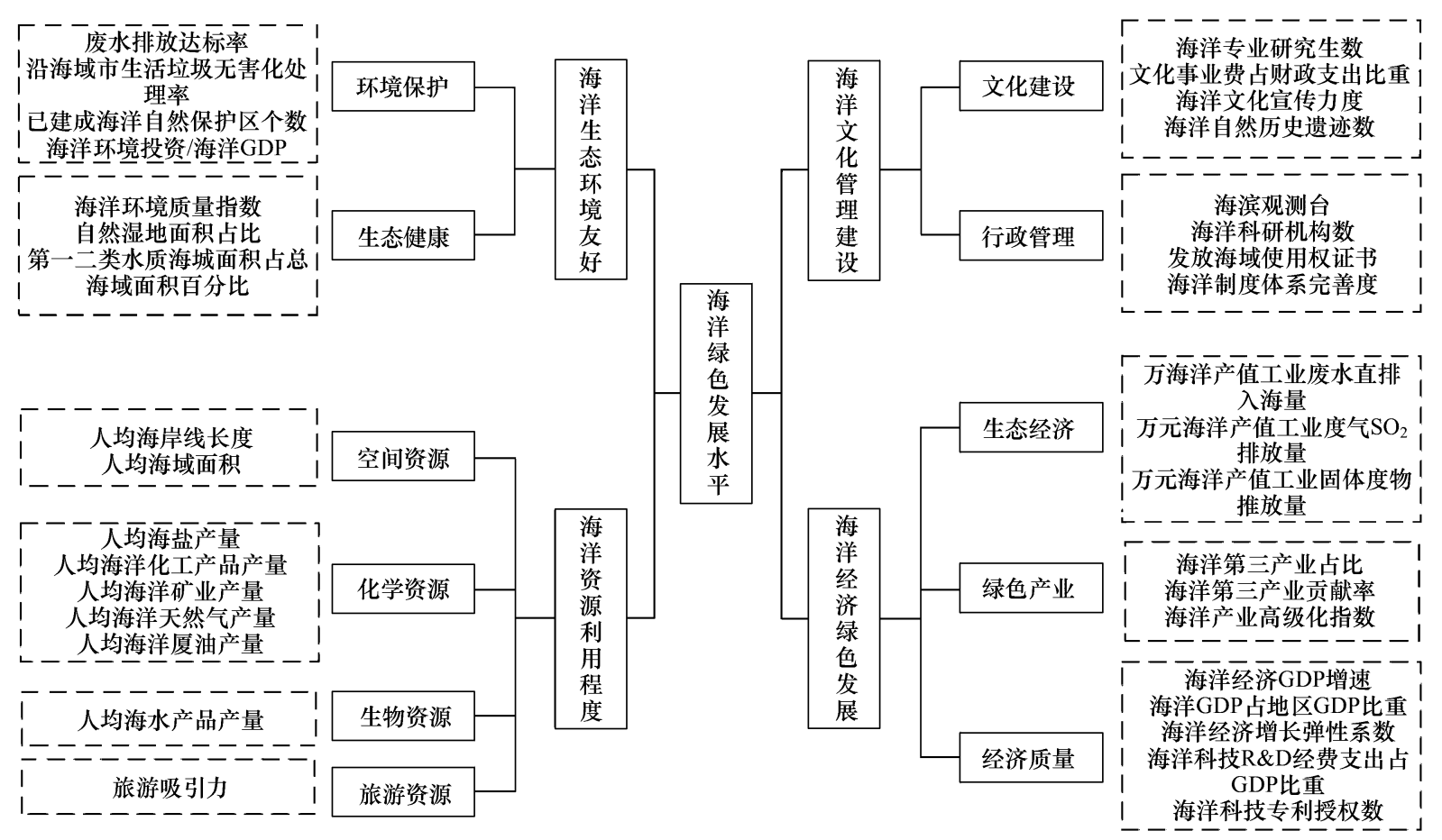

图 2 海洋绿色发展水平评价指标体系

Fig.2 Evaluation Index System of Marine Green Development level

\section{3 数据来源}

本研究采用 2006-2017 年的《中国统计年鉴》、《中国海洋统计年鉴》、《中国海洋环境质量公报》以及沿 海各省市海洋环境质量公报等公开的统计数据和资料, 个别数据部分年限缺失, 对无法获得的指标数据, 根据 实际情况用多重插补法进行填补和处理。关于定向指标量化,根据大量的参考文献以及《海洋统计年鉴》、 《中国统计年鉴》、《中国海洋统计年鉴》、《中国海洋环境质量公报》、沿海各省市海洋环境质量公报等公开的 统计数据和资料的查阅, 选取了相关的定量指标, 采用加权综合评价法将定量指标进行加权求和。旅游吸引 力: 人境过夜旅游者人均天花费、接待人境过夜游客人数、四、五星级饭店数、AAAAA 旅游景区数、AAAA 旅游 景区数、旅游景区营业收人、国际旅游 (外汇) 收人和海洋旅游宣传费用; 海洋制度体系完善度:海洋管理机构 个数、海域管理面积、海域使用权证书发布和海洋相关法律颁布条例数;海洋文化宣传力度:海洋文化馆个数、 
海洋文化宣传活动举办次数、海洋文化事业费支出、海洋专业研究生数。

\section{2 研究方法}

2.1 可变模糊识别模型 ${ }^{[33]}$

20 世纪 90 年代,陈守煜在札德模糊集合的基础上提出相对隶属度概念,建立工程模糊集 ${ }^{[34]}$ 。本文首次 将可变模糊识别模型运用于海洋绿色发展研究中, 可变模糊识别模型相对于其他方法而言, 能够科学、合理的 确定样本指标对各级指标标准区间的相对隶属度、相对隶属函数, 并且能够通过变化模型和参数, 组成新模 型, 分别对同一事物取平均值进行评价, 提高了评价结果的可信度和准确度 ${ }^{[35-36]}$ 。

模糊可变识别模型为:

$$
V_{A}(u)=1 /\left[1+\left(d_{g} / d_{b}\right)^{\alpha}\right]
$$

式中, $V_{A}(u)$ 为识别对象 $u$ 对 $A$ 的相对隶属度; $a$ 为优化准则参数, $a=1$ 为最小一乘方准则, $a=2$ 为最小二乘 方准则。

与左右极点的广义距离分别为:

$$
d_{g}=\left\{\sum_{i=1}^{m}\left[w_{i}\left(1-u_{A}(u)_{i}\right] p\right\}^{1 / p} \quad d_{b}=\left\{\sum_{i=1}^{m}\left[w_{i}\left(u_{A}(u)_{i}\right)\right]^{p}\right\}^{1 / p}\right.
$$

通常情况下, 模糊可变识别模型即公式 (1) (2) 中 $\alpha$ 与 $p$ 有四种搭配: 当 $\alpha=1, p=1$ 时, 为综合模糊评价模 型; 当 $\alpha=1, p=2$ 时, 为理想点模型; 当 $\alpha=2, p=1$ 时, 为 Sigmoid 型函数, 即 $\mathrm{S}$ 型函数, 可描述神经网络系统中 神经元的非线性特性或激励函数; 当 $\alpha=2, p=2$ 时, 为模糊优选模型。

级别特征值 $H(u)$ 公式如下:

$$
H(u)=\sum_{h=1}^{c}\left[V_{\sim}(u) \times h\right]
$$

再根据级别特征值最终评价沿海城市海洋绿色发展水平。

\section{2 空间马尔科夫链分析方法}

(1) 马尔可夫法 (Markov Chain) 是一种时间和状态均为离散的随即转移过程, 可以较好地分析海洋绿色 发展变化过程中的时间演变概率关系 ${ }^{[37]}$ 。具体公式: $P_{i j}=m_{i j} / m_{i}$, 其中 $P_{i j}$ 为 $t$ 年份 $i$ 类型的沿海省市在 $t+n$ 年 份转移到 $j$ 类型的概率, $m_{i j}$ 表示由 $t$ 年份 $i$ 类型的省市在 $t+n$ 年份的转移 $j$ 类型省市数量之和, $n_{i}$ 是所有年份 中属于 $i$ 类型的省市数量之和。

(2) 空间马尔可夫在传统马尔可夫的基础上加上了 “空间滞后”, 改善了传统马尔可夫不能够科学的揭示 区域的空间演变特征的缺陷,把两者结合起来,相互补充, 可以用来分析某区域的地理背景对该区域海洋绿色 发展水平演变的影响状况 ${ }^{[38]}$ 。该方法根据区域 $i$ 在初始年份里的空间滞后类型, 可以把传统的 $k \times k$ 马尔可 夫矩阵分成 $k$ 个条件转移矩阵。用 $P_{i j / k}(l)$ 表示 “在区域空间滞后 $k$ 类型的条件下,系统从 $t$ 年份 $i$ 类型经过 $l$ 步转移到 $j$ 类型的 $l$ 步空间转移概率”。

\section{3 面板数据模型}

本文采用面板数据模型进行影响因素分析,该方法便于控制个体的异质性,包含信息量大,能减少变量间 的共线性对结论的影响, 加大了自由度和估计的有效性, 也更加便于分析和动态调整。面数据回归模型包括 固定、混合、随机效应等,要根据研究运算不同的面板回归模型, 寻找模型最优解 ${ }^{[39]}$ 。

基于 2006-2017 年 11 省市面板数据,建立回归模型为:

$$
\ln Y_{i t}=C+\beta_{1} \ln X_{i t}+\beta_{2} \ln X_{i t}+\cdots+\beta_{k} \ln X_{i t}+\varepsilon_{i t}
$$

式中, $Y$ 表示海洋绿色发展水平; $i$ 表示我国沿海 11 省市; $t$ 表示时间序列 $(t=2006,2007, \cdots, 2017), \beta$ 是回归 参数; $\varepsilon_{i t}$ 是随机误差项。

\section{4 评价结果判断标准}

结合我国沿海省市区海洋经济现状和相关研究中可变模糊识别模型级别特征值判断标准 ${ }^{[00-41]}$, 本文将 
沿海地区海洋绿色发展水平分为 5 个等级,评判标准见表 1 。

表 1 海洋绿色发展水平判断标准

Table 1 Criteria for judging the level of Marine Green Development

\begin{tabular}{ccc||ccc}
\hline $\begin{array}{c}\text { 等级 } \\
\text { Level }\end{array}$ & $\begin{array}{c}\text { 判断标准 } \\
\text { Judging standard }\end{array}$ & $\begin{array}{c}\text { 范围 } \\
\text { Range }\end{array}$ & $\begin{array}{c}\text { 等级 } \\
\text { Level }\end{array}$ & $\begin{array}{c}\text { 判断标准 } \\
\text { Judging standard }\end{array}$ & $\begin{array}{c}\text { 范围 } \\
\text { Range }\end{array}$ \\
\hline 1 & 低水平 & {$[0-2)$} & 4 & 较高水平 & {$[3.5-4)$} \\
2 & 较低水平 & {$[2-3)$} & 5 & 高水平 & {$[4-5)$} \\
3 & 中等水平 & {$[3-3.5)$} & & \\
\hline
\end{tabular}

\section{3 中国海洋绿色发展综合水平分析}

\section{1 海洋绿色发展时间演化分析}

本文运用可变模糊识别模型对 12 年我国 11 个地区的数据进行测度研究,通过变化模型和参数,将模糊 综合评价模型、TOPSIS 理想点模型、Sigmoid 型函数模型、模糊优选模型 4 种数学模型组合并求平均数 ${ }^{[42]}$, 结 果如表 2 所示。

表 22006 -2017 年海洋绿色发展总体水平

Table 2 The green development level of marine from 2006-2017

\begin{tabular}{llllllllllllll}
\hline 年份 Year & 2006 & 2007 & 2008 & 2009 & 2010 & 2011 & 2012 & 2013 & 2014 & 2015 & 2016 & 2017 & 均值 Average \\
\hline$a=1, p=1$ & 2.98 & 2.99 & 3.02 & 3.12 & 3.16 & 3.23 & 3.27 & 3.32 & 3.36 & 3.41 & 3.36 & 3.48 & 3.23 \\
$a=1, p=2$ & 2.41 & 2.40 & 2.44 & 2.65 & 2.71 & 2.87 & 2.93 & 3.03 & 3.08 & 3.17 & 3.10 & 3.31 & 2.84 \\
$a=2, p=1$ & 2.83 & 2.84 & 2.89 & 2.99 & 3.02 & 3.08 & 3.14 & 3.18 & 3.21 & 3.25 & 3.21 & 3.33 & 3.08 \\
$a=2, p=2$ & 3.00 & 3.01 & 3.03 & 3.09 & 3.11 & 3.14 & 3.17 & 3.19 & 3.20 & 3.23 & 3.21 & 3.27 & 3.14 \\
均值 Average & 2.80 & 2.81 & 2.85 & 2.96 & 3.00 & 3.08 & 3.13 & 3.18 & 3.21 & 3.27 & 3.22 & 3.35 & 3.07 \\
\hline
\end{tabular}

海洋绿色发展的进程是持续不断的,2015 年中央政治局会议上审议通过的《关于加快推进生态文明建设 的意见》中, 首次提出海洋绿色化概念, 因此海洋绿色发展水平较低,发展历程较短。由表 3 可以看出, 12 年 间中国海洋绿色发展水平总体呈现上升趋势,并且从 2006 年的 2.8 上升到 2017 年的 3.35 , 增幅达到 19.6\%, 我国海洋绿色发展水平的平均评价值为 3.07 , 总体为中等水平, 反映出我国海洋绿色发展水平有待提高。 2006-2008 年的综合评分处于较低等级,说明早期海洋绿色发展水平较低。

为分析我国海洋绿色发展水平的时间演变形势,本文选取了三个比较有代表性年份 2006 年、2011 年和 2017 年的综合得分,运用 Eviews8.0 对选取数据进行核 密度估计,得出核密度二维图(图 3)。图中横轴表示海 洋绿色发展得分,纵轴表示核密度,通过不同时期对比, 得出了我国海洋绿色发展水平的动态演化特征。

(1) 从位置上, 3 个年份的密度函数的中心点呈现 了向右移动的显著趋势,说明我国海洋绿色发展水平有 着明显的提升,核密度曲线波峰对应的海洋绿色发展水 平在 2011-2017 年逐渐增大,说明整个区域正在形成 一个快速全面的发展格局。

(2) 从形状上,2006 年核密度曲线虽呈现正态分布 趋势,但波峰较为平坦,说明各省海洋绿色发展水平分 布比较分散,海洋绿色发展水平低分低的省份占比较

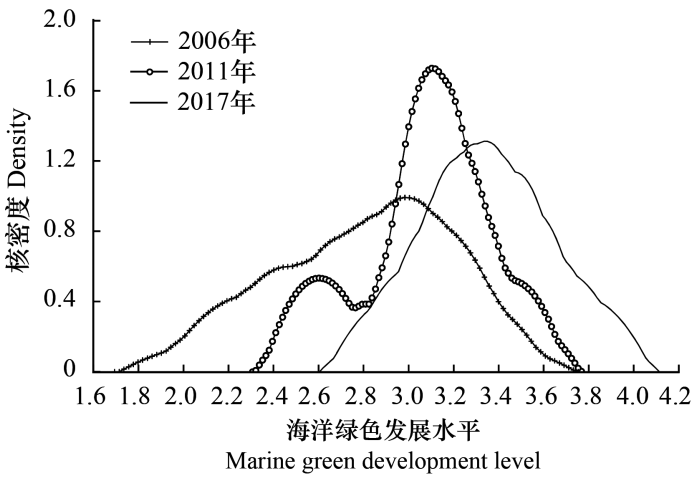

图 3 我国沿海城市海洋绿色发展水平 Kernel 密度分布 Fig.3 Kernel density distribution of marine green development level in coastal cities 大,并且海洋绿色发展分布比较均衡,基本呈对称分布; 
2011 年呈现了双峰分布状态, 说明海洋绿色发展呈现多极分化; 到 2017 年, 呈现单峰状态, 多极化程度有了 改善,发展趋于均衡。

(3) 从峰值变化上,2006 年峰值比较低, 说明总体海洋绿色发展程度偏低, 只有少数地区 (广东、上海等) 发展水平较高, 和少数地区 (河北、广西等) 发展水平较低,其余地区发展水平分布均匀。2011 年,出现双峰状 态, 并且第二个峰的峰值明显大于第一个峰值, 说明低水平地区和高水平地区占比少于中等发展水平地区。 到 2017 年时, 变成单峰状态, 并且峰值有着明显下降的趋势, 这说明我国海洋绿色发展较高的地区数量有增 加的趋势, 地区间差异也会不断缩小。

\section{2 海洋绿色发展空间演化分析}

为研究 2006-2017 年沿海各省市海洋绿色发展水平空间演化特征, 本文选取了 2007 年、2011 年和 2017 年的各省市海洋绿色发展水平评分结果, 使用 Arcgis 空间分析技术, 对海洋绿色发展水平空间演化现状进行 分析 (图 4)。从整体上看,三个时间断面的海洋绿色发展水平均呈现明显的空间分异特征, 沿海 11 省市没有 绿色发展高水平、低水平的地区,整体发展水平位于较低水平和较高水平之间。根据海洋绿色发展水平的基 尼系数和变异系数计算结果, 发现它们的变动趋势基本一致,基尼系数介于 $0.11-0.133$ 之间, 2006 年到 2017 年,一直处于下降趋势, 从 2006 年的 0.133 降到 2017 年的 0.11 , 说明虽然海洋绿色发展水平区域差异一直在 不断缩小, 但是依然存在差异。

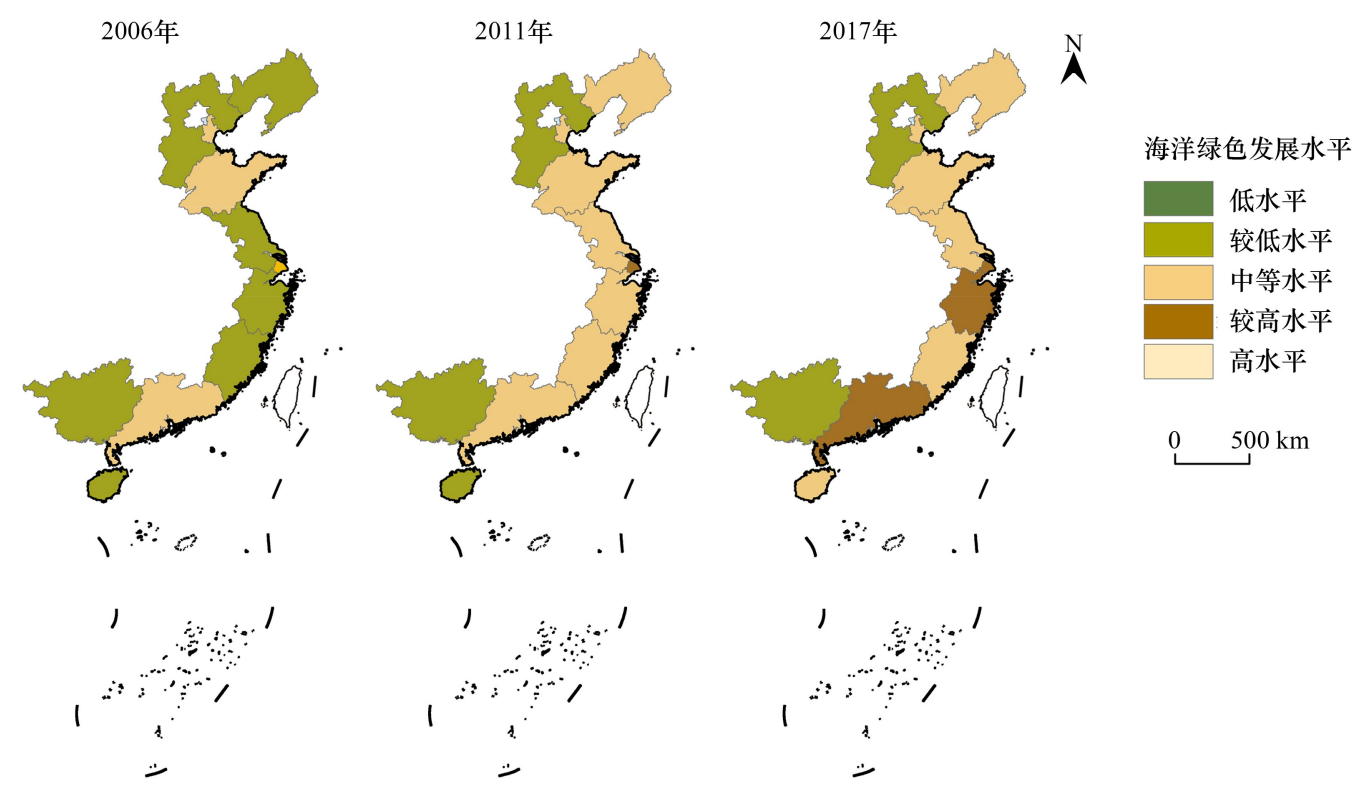

图 42006 - 2017 中国沿海城市海洋绿色发展水平空间分布

Fig.4 Spatial distribution of Marine green development level in coastal cities of China from 2006 to 2017

(1) 第一类:广东、上海和浙江; 其中上海海洋绿色演化特征为中一较高一较高, 到 2017 年上海海洋绿色 发展水平达到 3.74, 处于全国前列。广东的演化特征为中等一中等一较高, 广东早期虽然海洋经济绿色发展 水平排名靠前,但广东人口密集,活动频繁, 导致海洋生态环境破坏严重。2011 年之后, 广东积极规划和构建 三大海洋经济合作圈, 2017 年海洋绿色发展水平达到 3.79。浙江的演化特征是较低一中等一较高, 浙江是沿 海省份中海洋绿色发展水平发展最快的, 属于长江三角洲经济带城市群, 和相邻江苏省发展优势不同, 可以互 相学习优势, 最后协同发展。

(2)第二类: 天津、山东、福建、江苏; 天津发展演化特征为中等一中等一中等, 2006 到 2017 年, 海洋绿色 发展水平从 3.17 到 3.29, 天津因为京津冀经济圈建设以及环渤海位置优势, 优先发展海洋经济, 但由于人们 对海洋文化认知程度不高, 海洋发展意识薄弱, 近些年天津填海造地需求量大, 海洋生态环境破坏严重, 因此 
后续发展缓慢。山东省作为临海大省, “海上山东”战略实施以来, 海洋经济就开始迅速发展, 2015 年, 山东被 确定为 “一带一路” 规划海上战略支点, 在海洋经济方面又获取了新的动力。福建的演化特征为较低一中 等一中等,2006-2017 年增长率达到 20.1\%, 海洋发展潜力巨大。江苏省作为经济强省,海洋经济没有得到 重视, 因此在海洋发展程度上落后于其他省份, 到 2017 年江苏海洋绿色发展才增长到 3.38 , 处于中等水平, 但 是江苏省海洋发展势头向好,速度较快。

(3) 第三类:辽宁、海南、河北和广西。21世纪初,辽宁作为东北地区沿海省市,大力实施“海上辽宁,科技 兴海” 战略, 海洋绿色发展水平增长较快。但是近些年海洋产业结构转型升级程度不高、海洋科技落后和资 源利用程度不高等问题都导致海洋发展滞后, 2012-2017 年,辽宁海洋绿色发展水平增长率只有 3.2\%。海 南虽然地理位置优越, 四面环海, 海洋交通方便, 资源丰富, 但是海南海洋经济规模小, 科研投人力度不够, 海 洋产业结构也有待优化,所以海洋绿色发展水平仍然不高。河北、广西在 2017 年海洋绿色发展水平都仍处于 较低水平; 河北虽紧邻京津, 地理位置优越,但海洋发展起步较晚, 总体规模依然弱小, 与沿海发达省份相比差 距仍然较大, 现代海洋产业发展水平滞后, 海洋经济绿色发展程度低, 污染治理力度不够, 资源也未得到充分 开发利用。广西 2006-2017 年海洋绿色发展一直处于较低水平, 虽然总体有提升, 年均增长达到 3.4\%, 但是 由于前期发展水平太低, 提升空间有限。

\section{3 海洋绿色发展水平时空动态演化特征}

为进一步分析沿海省市海洋绿色发展水平的动态演化过程, 利用 MATLAB 软件, 分别计算 2006-2011 年和 2012-2017 年两个时间段的马尔科夫转移概率矩阵 (表 3)。海洋绿色发展结果被分为 5 类,分类情况 见表 1 , 但由于海洋绿色发展低水平和高水平省份都为零, 为遵循马尔可夫分类原理, 将 $[0-3)$ 归为较低水 平, [3-3.5) 为中等水平, [3.5-5) 归为较高水平。

表 $32006-2017$ 年海洋绿色发展水平类型的马尔可夫转移矩阵

Table 3 Non-spatial Markov-chain transitional matrix for green development level of marine from 2006-2017

\begin{tabular}{cccccc}
\hline $\begin{array}{c}\text { 年份 } \\
\text { Year }\end{array}$ & $\begin{array}{c}\text { 类型 } \\
\text { Type }\end{array}$ & $\begin{array}{c}\text { 区域数量 } \\
\text { Area quantity }\end{array}$ & $\begin{array}{c}\text { 较低水平 } \\
\text { Lower level }\end{array}$ & $\begin{array}{c}\text { 中等水平 } \\
\text { Medium level }\end{array}$ & $\begin{array}{c}\text { 较高水平 } \\
\text { High level }\end{array}$ \\
\hline \multirow{2}{*}{$2006-2011$} & 较低水平 & 34 & 0.79 & 0.21 & 0.00 \\
& 中等水平 & 31 & 0.00 & 0.97 & 0.03 \\
& 较高水平 & 1 & 0.00 & 0.00 & 1.00 \\
$2012-2017$ & 较低水平 & 12 & 0.81 & 0.19 & 0.00 \\
& 中等水平 & 42 & 0.00 & 0.81 & 0.19 \\
& 较高水平 & 12 & 0.00 & 0.08 & 0.92 \\
\hline
\end{tabular}

在表 3 中,海洋绿色发展水平类型随时间演变,其中对角线元素数值代表的是绿色发展水平类型没有发 生变化的概率, 非对角线元素的数值代表的是不同类型发生转移的概率。2006-2011 年、2012-2017 年对角 线元素数值都比较大, 说明各个省市海洋绿色发展水平比较稳定, 海洋绿色发展水平类型虽然存在转移, 但是 幅度不大, 表明海洋绿色发展受到生态环境和资源的限制。2006-2011 年非对角线元素数值中, 大部分转移 概率为 0 , 说明在两个连续的年份中, 区域的海洋绿色发展不会发生跃迁, 这与海洋绿色发展本身的连续性有 关。2006-2011 年较高水平的保持概率是 100\%,2012-2017 年为 92\%,这说明在发展中发达地区有内部趋 同现象。绿色发展水平向上转移较为明显,2006-2011 年较低水平向中等水平转移概率为 21\%,2012-2017 年则为 $9 \%$, 说明较低水平向中等水平转移概率减小, 较低水平数量逐渐减小,逐渐趋于稳定;2006-2011 年 中等水平转化为较高水平的概率小于 2012-2017 年,2011 年之后,中等水平向较高水平转化比较活跃。

使用传统的马尔可夫链分析法无法呈现不同区域背景下海洋绿色发展水平类型的转移情况,表 4 是基于 空间滞后的空间马尔可夫模型的分析结果。 
表 $42006-2017$ 年海洋绿色发展类型的空间马尔可夫转移矩阵

Table 4 Spatial Markov-chain transitional matrix for green development level of marine from 2006-2017

\begin{tabular}{|c|c|c|c|c|c|c|c|}
\hline \multirow{2}{*}{$\begin{array}{l}\text { 类型 } \\
\text { Type }\end{array}$} & & \multicolumn{3}{|c|}{$2006-2011$} & \multicolumn{3}{|c|}{$2012-2017$} \\
\hline & & 较低水平 & 中等水平 & 较高水平 & 较低水平 & 中等水平 & 较高水平 \\
\hline \multirow[t]{3}{*}{ 较低水平 Lower level } & 较低水平 & 0.945 & 0.055 & 0.000 & 0.930 & 0.070 & 0.000 \\
\hline & 中等水平 & 0.000 & 0.870 & 0.130 & 0.000 & 0.750 & 0.250 \\
\hline & 较高水平 & 0.000 & 0.000 & 1.000 & 0.000 & 0.120 & 0.880 \\
\hline \multirow[t]{3}{*}{ 中等水平 Medium level } & 较低水平 & 0.815 & 0.185 & 0.000 & 0.743 & 0.257 & 0.000 \\
\hline & 中等水平 & 0.000 & 0.889 & 0.111 & 0.000 & 0.821 & 0.179 \\
\hline & 较高水平 & 0.000 & 0.000 & 1.000 & 0.000 & 0.091 & 0.909 \\
\hline \multirow[t]{3}{*}{ 较高水平 Higher level } & 较低水平 & 0.765 & 0.345 & 0.000 & 0.000 & 0.000 & 0.000 \\
\hline & 中等水平 & 0.000 & 0.919 & 0.081 & 0.000 & 0.897 & 0.103 \\
\hline & 较高水平 & 0.000 & 0.000 & 1.000 & 0.000 & 0.059 & 0.941 \\
\hline
\end{tabular}

由表 3 和表 4 可知,相邻区域环境能对一个区域经济类型变动的影响,并且整体呈现“俱乐部趋同”的趋 势。由表 4 可知,任何区域都不是孤立的,都与周围区域的发展水平有比较大的相关性。(1)发展类型较高的 省区对相邻的省区有显著的正溢出影响,反之,较低省市对相邻省市有负溢出影响。例如:2006-2011 年, 在 表 3 中, 较低水平和中等水平向上转变的概率为 $21 \% 、 3 \%$ 。但在表 4 中, 在与较高水平地区相邻时,其向上转 变的概率则增长为 $34.5 \% 、 8.1 \%$; 反之, 2012-2017 年, 在表 3 中, 较高水平地区向下转移的概率为 $8.0 \%$, 但 是, 与较低水平和中等水平为邻域时, 概率上升为 $12 \% 、 9.1 \%$ 。(2)对于较低水平的区域, 若以中等水平地区为 邻, 在 2006-2011 年间向上转移的概率增加 13\%, 而以较高水平地区为邻时向上转移的可能性增加 $16 \%$, 增 加更为明显。(3)一个区域若以较低水平区域为邻, 将受到负面影响, 而以较高水平为邻, 则可以有效地提高其 向上转移的可能性,阻止其向下转移的可能性,也就是“俱乐部趋同”, 如: 以较低水平为邻时,在 2006-2011 年期间, 较低水平地区停滞落后水平的概率为 $94.5 \%$, 而当它与较高水平地区为邻时, 停滞落后的概率就降低 为 76.5\%。因此, 海洋绿色发展的演变受区域背景影响, 高水平地区带动周边地区共同发展, 低水平地区制约 周边地区发展,使区域类型向更低水平转移概率增大, 导致在空间上呈现集聚格局。

\section{4 海洋绿色发展水平分系统分析}

4.1 海洋绿色发展分系统时间演化

为分析各系统时间演变规律, 本文利用可变模糊识别模型对分系统进行计算分析 (图 5)。总体而言, 从 2006 年到 2017 年, 四个系统都呈现增长趋势, 2006-2017 年海洋经济绿色发展水平增速缓慢,2008 年还出现 一定程度的下降, 这与当年国际金融危机对经济带来的影响有关, 也由此看出海洋经济虽然取得了很大的发 展, 但是绿色程度不够, 需要转化发展模式, 打造海洋现代化经济体系, 实现海洋经济绿色高水平发展。海洋 生态环境和海洋资源虽然都有一定程度的增长, 但是水平依然不高, 增长幅度缓慢, 海洋生态环境年增长率为 $1.5 \%$, 海洋资源利用年增长率只有 $0.77 \%$ 。早期我国注重陆地发展, 海洋文化传播方面一直不够重视, 所以海 洋文化管理建设整体水平不高, 从 2006 年的 2.25 到 2017 年的 2.29 , 总增长率只有 $0.62 \%$ 。因此需要加大对 海洋文化管理的重视, 完善海洋制度体系, 加大海洋文化宣传, 提高海洋绿色发展的软实力, 为海洋绿色发展 提供保障。

\section{2 海洋绿色发展分系统空间演化}

为了进一步研究海洋绿色发展水平差异存在的原因, 本文对分指标的评分进行分析, 了解区域海洋绿色 发展水平的存在问题。

(1)海洋生态环境友好是海洋绿色发展的直观体现,也是海洋绿色发展的关键(图 6)。其中上海、辽宁、山 东和海南海洋环境状况相对较好, 海南近海领域水质最好, 上海污染处理率最高, 海洋自然环境保护建设投人 最大, 海洋环境质量指数高, 但是近海领域水质由于人类活动频繁和处于长江人海口地界, 一直处于三、四等 
水质。河北、广东、福建在沿海省市中海洋生态环境较差,需要在海洋经济发展的同时注重环境保护。

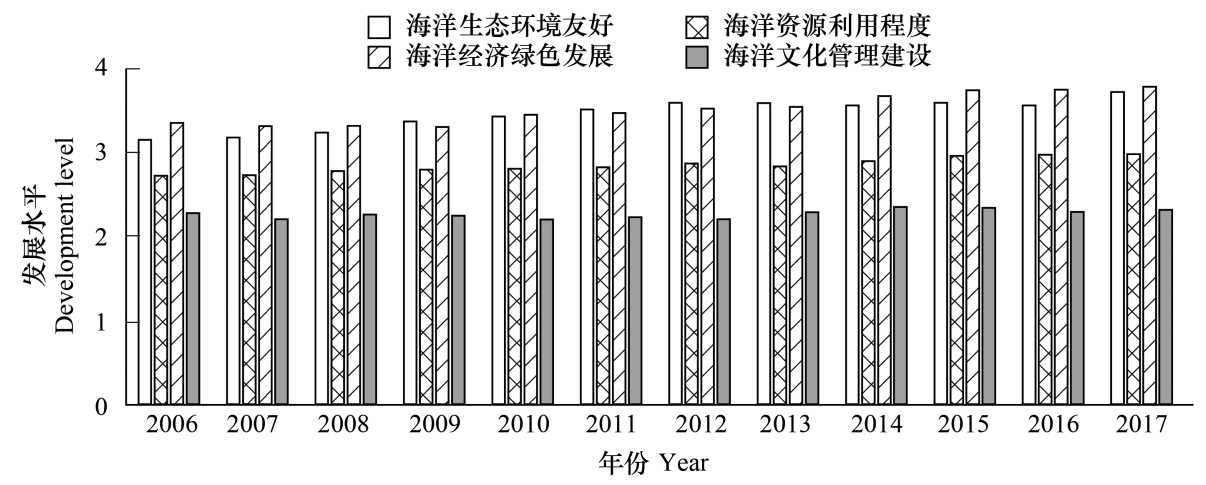

图 $52006-2017$ 年海洋绿色发展分系统时间演化

Fig.5 Time evolution of marine green development subsystem 2006-2017
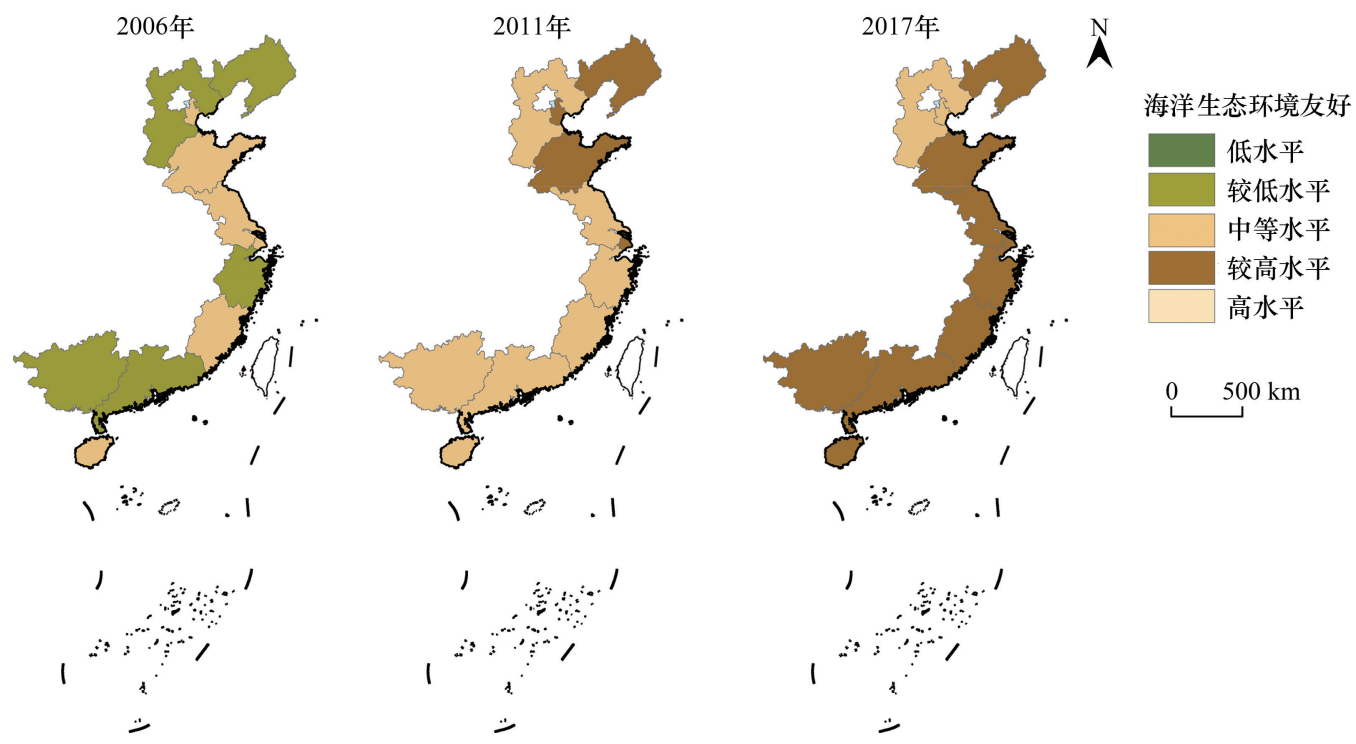

图 6 海洋生态环境友好空间分布

Fig.6 Spatial distribution of Marine Eco-environmental friendliness

(2)海洋资源利用是海洋绿色发展的根基(图 7)。中国海洋资源由于开发利用程度不高,过度开发导致海 洋生物资源衰退, 开发技术落后, 近海领域污染问题, 整体水平处于中等偏下。广西海洋资源利用属于低水 平, 广西资源虽然较丰富, 但开发利用程度不高, 可以合理加大资源的开发利用率。河北在海洋研究机构和海 洋技术人员上远少于同为环渤海的山东、天津和辽宁, 海洋科技支撑力不足, 资源综合利用率较低, 上海、广 东、福建的海洋资源利用相对处于领先地位。

(3)海洋经济绿色发展是海洋绿色发展的途径 (图 8)。江苏省海洋 GDP 占地区 GDP 占比在 2016 年仅有 $8.5 \%$, 海洋第三产业占比也低于其他省份, 因此江苏海洋经济绿色发展水平虽然逐年增长, 但是一直处于中 等水平, 直到 2017 年才达到较高水平。广东、上海、福建和浙江属于第一梯队, 海洋经济绿色发展迅速, 在海 洋创新技术和产业结构上也比较成熟。海南、山东、江苏属于第二梯队, 辽宁、天津属于第三梯队,河北和广西 属于第四梯队, 河北和广西将发展重点放在陆域经济, 海洋产业结构水平低, 海洋科技创新能力低, 经济产出 能耗高等都是造成广西、河北经济绿色发展水平落后的原因。 


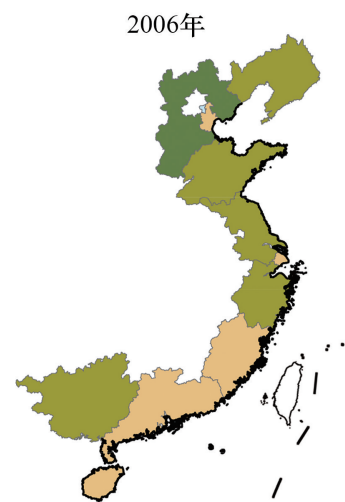

$1 \therefore \Leftrightarrow .1$

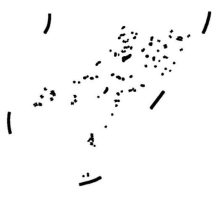

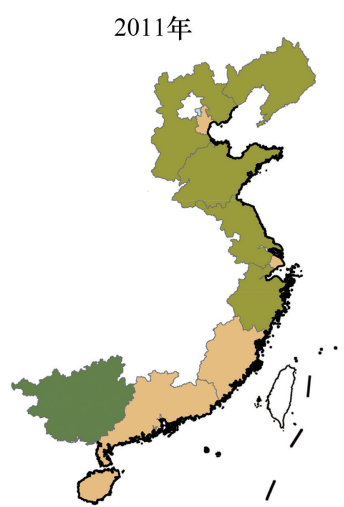

$\because \because 2.1$

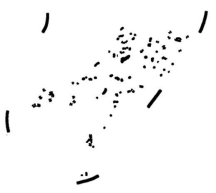

图 7 海洋资源利用程度空间分布

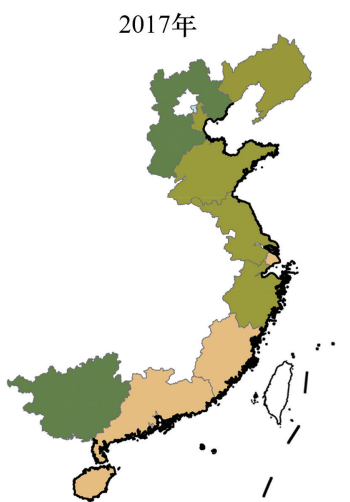

1) $\because \because .1$

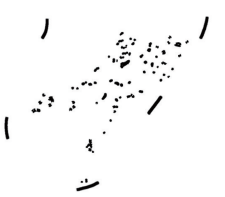

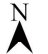

海洋资源利用程度

低水平

较低水平

中等水平

较高水平

高水平

$0 \quad 500 \mathrm{~km}$

Fig.7 Spatial distribution of marine resources utilization

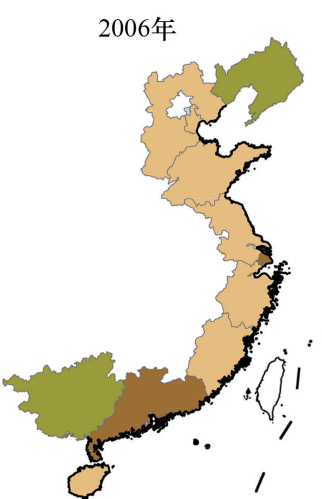

$1 \because \because .1$

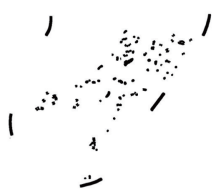

2011年

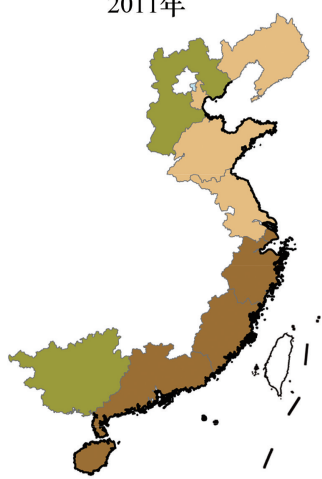

$1 \therefore \Leftrightarrow .1$

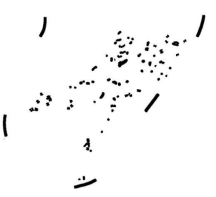

2017年

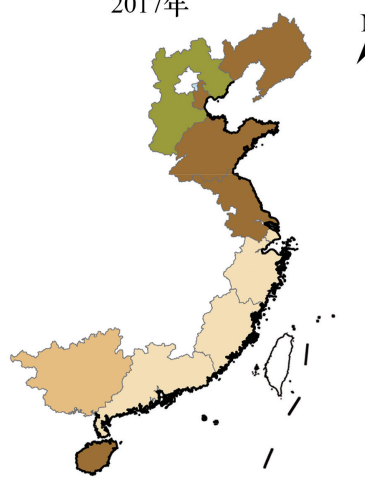

$1 \therefore \varnothing .1$

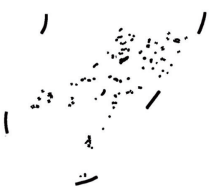

图 8 海洋经济绿色发展的空间分布

Fig.8 Spatial distribution of green growth in marine economy

(4)海洋文化管理建设是海洋绿色发展水平的保障(图 9)。海洋文化管理建设依托于海洋文化资源丰富、 海洋资源文化开发、海洋文化宣传和海洋法律制度完善。其中广东、浙江、上海属于第一梯队, 文化宣传和海 洋管理法律相对完善,但是仍然存在不足,所以 2017 年仍然没有突破高水平。辽宁、山东、江苏、福建等省市 差距不明显, 都处于中等水平, 天津、海南、河北、广西属于第三梯队, 河北、广西海洋发展整体处于中等偏下水 平,海洋文化宣传和海洋管理方面力度不够。 


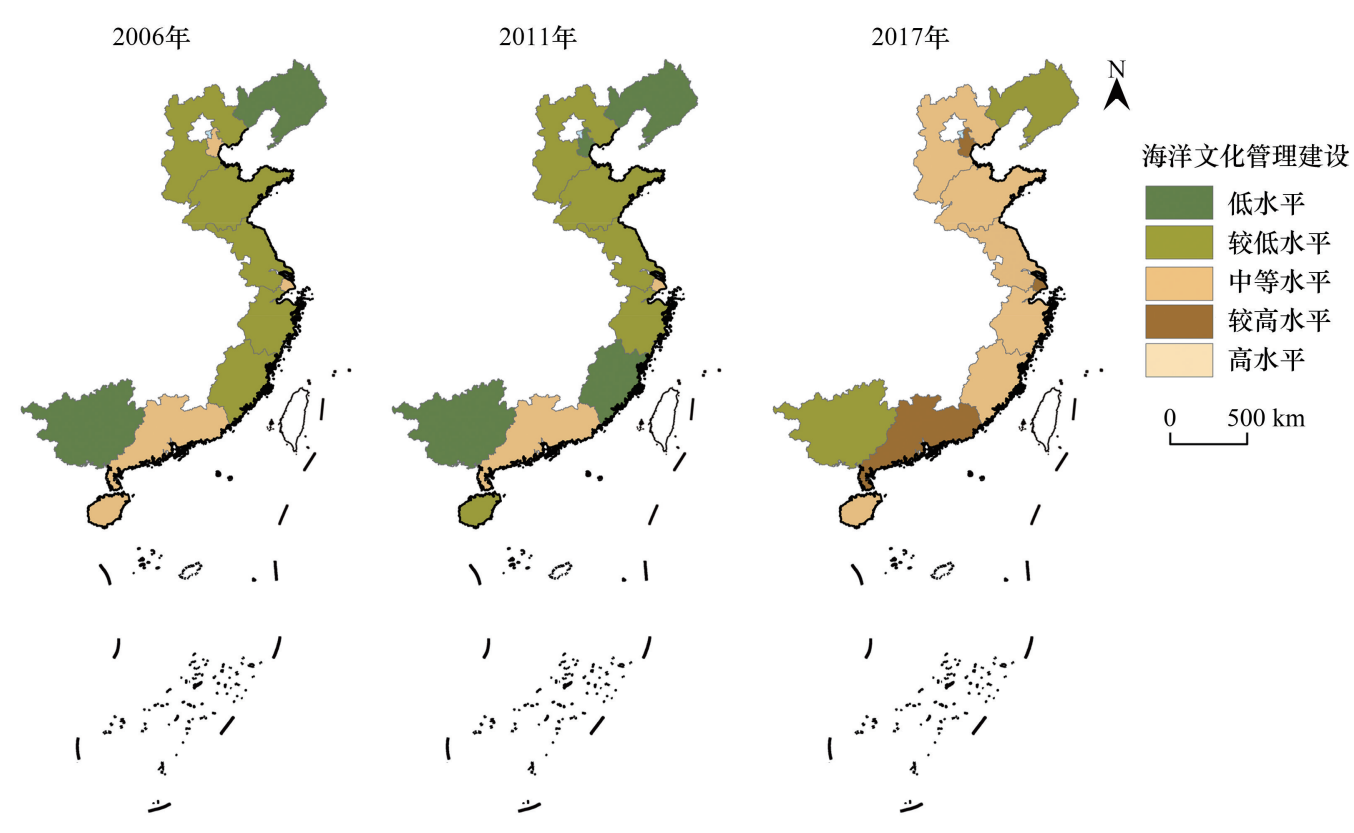

图 9 海洋文化管理建设的空间分布

Fig.9 The spatial distribution of the construction of marine cultural system

\section{5 海洋绿色发展水平的影响机理研究}

\section{1 模型构建}

通过对上述中国沿海各省市海洋绿色发展及其构成指数的整体空间分布特征进行分析, 可以发现中国各 省市海洋绿色发展及其构成指数具有明显的空间集聚和分异特征。结合中国海洋发展所面临的新形势、新问 题,剖析海洋绿色发展所面临的外部环境问题,分析多要素作用机理下,中国海洋绿色发展的时空演变与空间 集聚。

本文以海洋绿色发展 (MGD) 为被解释变量, 根据上文,选取了相关性程度较高的内部影响因素指标为海 洋产业结构 (MIS)、海洋管理 (MO)、海洋资源利用 (RES)、海洋科技创新 (MTE)。并且基于已有关于海洋发 展的研究,选取外部影响因素指标为:政府调控 (GE)、陆域经济水平 (LE)、就业潜力 (EMP)、开放程度 (OL)、 环境治理 $(\mathrm{EA})^{[23,43-45]}$ 。分别用海洋产业高级化指数、沿海海滨观测站台数、海域集约利用指数(海洋产业产 值/确权海域面积)、海洋科研机构技术人员本科以上学历比重、海洋科研机构基本建设中政府投资 (万元)、 人均 GDP、涉海从业人员数、沿海地区进出口 GDP 占 GDP 比重、海洋环境治理投资额来表示。本文根据各影 响因素的评估参数, 研究形成海洋绿色发展动态演变综合驱动机制整体框架(图 10)。

\section{2 面板数据的单位根检验和 Hausman 检验}

为避免模型分析结果出现 “伪回归”,本文采用 LLC、IPS、ADF-Fisher 和 PP-Fisher 单位根检验方法对面板 数据进行平稳性检验 ${ }^{[46-47]}$ 。运用 stata14.0 软件检验所有数据的对数数列, 虽然检查结果存在一或两个模型 非平稳现象,但仍然存在两个或多个模型结果为平稳。在单位根检验模型中, 只有当所有模型检验结果均表 现为非平稳时, 结论才为时间序列非平稳, 只要其中有一个模型的结果拒绝了原假设, 就认为序列是平 稳的 ${ }^{[48]}$ 。

在数据进行回归分析之前, 通常需要进行检验, 才能进一步选择到底采用混合估计模型、固定效应模型还 是随机效应模型, 本文先对数据进行 $F$ 检验, $F$ 检验设定原假设用混合估计变量, 结果 $P r o b=0.00<0.05$, 因此 拒绝原假设; 再对结果进行 Hausman 检验, Hausman 检验设定原假设为随机变量, 结果 $P r o b=0.00<0.05$, 也就 


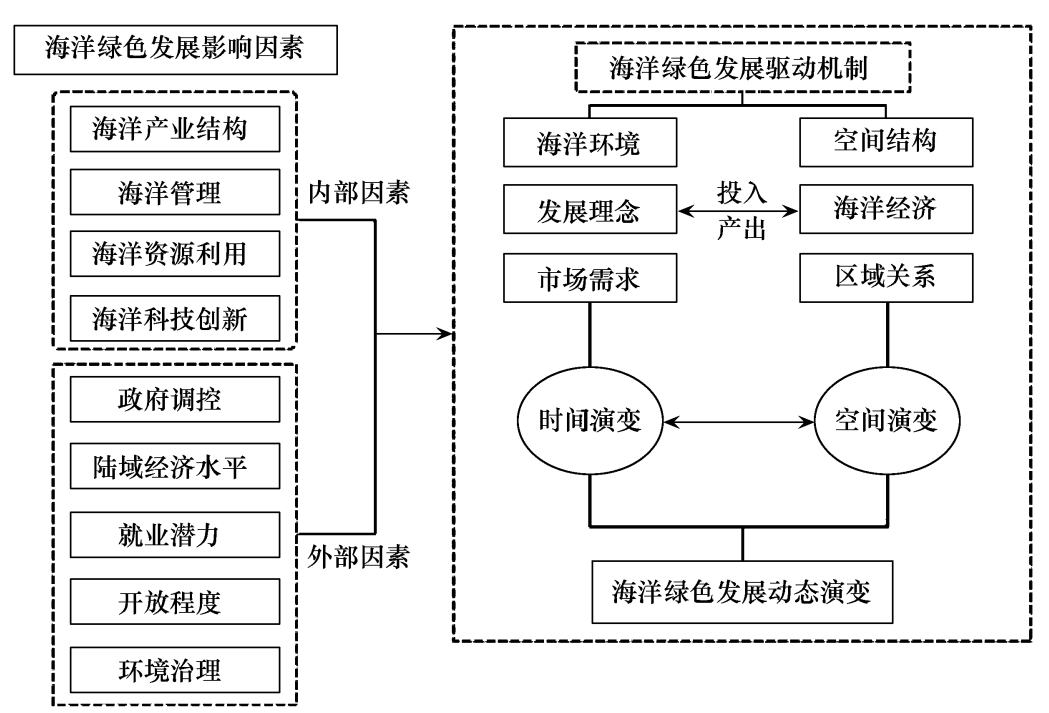

图 10 海洋绿色发展影响因素

Fig.10 Impact of marine green development

是拒绝了原假设,因此本文采用固定效应模型回归结果进行分析。考虑沿海各省份海洋绿色发展存在差异, 选择变截距固定效应模型作为研究面板回归的模型,计算结果如表 5 所示。

表 5 影响因素面板回归

Table 5 Influencing factor panel regression results

\begin{tabular}{|c|c|c|c|c|c|c|c|}
\hline $\begin{array}{l}\text { 变量 } \\
\text { Variable }\end{array}$ & $\begin{array}{c}\text { 回归系数 } \\
\text { Regression coefficient }\end{array}$ & $\begin{array}{c}T \text { 值 } \\
T \text { Value }\end{array}$ & $P$ & $\begin{array}{l}\text { 变量 } \\
\text { Variable }\end{array}$ & $\begin{array}{c}\text { 回归系数 } \\
\text { Regression coefficient }\end{array}$ & $\begin{array}{c}T \text { 值 } \\
T \text { Value }\end{array}$ & $P$ \\
\hline $\operatorname{lnMIS}$ & 1.902759 & 2.61 & $0.026^{* *}$ & $\operatorname{lnLE}$ & 0.1861595 & 5.73 & $0.000^{* * *}$ \\
\hline $\operatorname{lnMO}$ & 0.0867146 & 1.87 & 0.091 * & $\operatorname{lnEMP}$ & 0.0308841 & 1.34 & 0.179 \\
\hline $\operatorname{lnRES}$ & 0.0299292 & 2.67 & $0.023^{* *}$ & $\operatorname{lnOL}$ & 0.0705073 & 3.19 & $0.001^{* * * *}$ \\
\hline lnMTE & -0.314493 & -0.66 & 0.525 & $\operatorname{lnEA}$ & -0.0680256 & -5.53 & $0.00^{* * *}$ \\
\hline $\operatorname{lnGE}$ & 0.0126903 & 4.11 & $0.000^{\text {**** }}$ & con & 0.8674659 & 17.59 & 0.000 \\
\hline
\end{tabular}

1.海洋产业结构 (MIS)、海洋管理 (MO)、海洋资源利用 (RES)、海洋科技创新 (MTE)、政府调控 ( GE)、陆域经济水平 (LE)、就业潜力 ( EMP) 、开放程度 $(\mathrm{OL})$ 和环境治理 $(\mathrm{EA}) ; 2$. “ ” “ “**” 和 “ *** $*$ 分别表示估计值在 $10 \% 、 5 \%$ 和 $1 \%$ 的显著性水平下显著

由表 5 可知: (1) 政府调控、陆域经济水平和开放程度对于海洋绿色发展水平都有显著的正向相关关系 且都通过了 $99 \%$ 的显著性检验。平均政府投资加大 1 个单位,海洋绿色发展增加 0.013 , 政府能提供强大的科 技支撑、能更好的优化产业结构和资源配置, 从而推动海洋绿色发展,早期政府 “重陆轻海”,对海洋发展投人 不足,随着“海上丝绸之路”、“陆海统筹”等海洋战略规划的提出,政府重心开始偏向海洋,也加大了对海洋高 新技术产业的投资,高新技术产业的发展使得海洋绿色发展水平提高; 陆域经济水平对于海洋经济的发展影 响力度较大,陆域经济水平提升 1 单位, 海洋绿色发展水平提升 0.186 , 海洋经济作为陆地经济的延伸, 起步比 较晚, 对陆域经济依耐性较强, 联系紧密; 结果显示, 扩大开放程度一个单位,海洋绿色发展水平只提高 0.07 , 说明扩大开放虽然对海洋绿色发展影响显著但同时也存在发达国家为改善海洋环境,将高污染和高消耗的产 业向中国转移的现象, 因此对外开放水平的提高虽然有利于海洋发展但是对于海洋绿色发展影响力度不大。

(2)海洋产业结构和海洋资源利用对海洋绿色发展的影响有正向显著影响,且通过了 $5 \%$ 以下的显著性 检验。海洋产业高级指数提高 1 个单位,海洋绿色发展提高 1.9 的单位,金融危机之后, 沿海各省市不断优化 海洋产业结构, 海洋产业比例逐渐趋于合理, 第三产业 “稳定器” 功能更加突出, 海洋资源环境的损耗也相对 减小, 这也是海洋产业高级化对海洋绿色发展影响相对较强的原因; 海洋资源利用率提高一个单位,海洋绿色 
发展仅提高 0.03 ,多年来海洋经济的粗放发展以及海洋资源利用率低下,导致海洋资源的浪费,但随着近年来 可持续发展理念的提出和科技水平的提高,海洋资源的利用效率逐渐高效,海洋绿色发展水平也得到了提升。

(3) 海洋管理对海洋绿色发展的通过了 $10 \%$ 的正向显著性检验,影响系数为 0.087 。一个地区的海洋管 理体系的完善与否, 直接影响了海洋的健康可持续发展, 而因为我国海洋法制建设起步较晚, 所以导致海洋管 理建设缓慢滞后, 对海洋绿色发展影响不明显。中共“十八大”提出建设海洋强国后, 先后制定了《中华人民 共和国海域使用管理法》、《中华人民共和国渔业法》等相关法律。随着海洋管理法律法规体系的完善和相关 法律的颁布,海洋管理管控体系会逐渐完善,也为海洋绿色发展提供了保障。

(4) 环境治理系数为负, 且通过了 $1 \%$ 以下的显著性检验, 说明环境对于海洋生态环境可持续发展具有潜 在的不利影响,但这并不说明加大环境治理力度会阻碍海洋的绿色发展, 出现这种现象的原因与海洋生态环 境污染依然严峻以及海洋生态环境治理依然不足有关。地方政府对于海洋环境治理的重视不够、投人不足, 海洋工业快速发展带来的污染效应大于环境保护的治理效应。因此沿海省市需要加强对海洋的环境治理投 资和自然保护区建设,才能将环境带来的负向影响变成正向推动。

(5) 海洋科技创新和就业潜力对于海洋绿色发展影响为不显著。海洋科技创新对海洋绿色发展有负向 的不显著影响,这与我国海洋科技成果的供给质量和效率不高以及科技投入的滞后效应有关,我国海洋科技 创新在部分关键核心技术领域与发达国家有差距, 真正意义上的海洋成果转化率并未达相应水平,创新动力 不足, 对海洋绿色发展影响不明显; 就业潜力对海洋绿色发展有不显著的正向影响, 劳动力的增加给海洋经济 发展带去了动力, 也因此促进了海洋的绿色发展, 但中国就业人口供大于求, 高新技术创新人才不足, 对于海 洋绿色发展的影响不显著。

\section{6 结论与建议}

\section{1 结论}

(1) 从总体来看,绿色发展指数整体呈现上升趋势,但地区差异问题依然存在; 在空间分布上,空间集聚 特征依然明显, 东南沿海地区总体海洋绿色发展水平相对较高, 西南和东北部分地区海洋绿色发展水平相对 较低;海洋绿色发展水平存在显著的空间溢出效应, 2006-2011 年多为较低水平向中等水平的转移, 20122017 年多为中等水平向较高水平的转移,且区域背景对海洋绿色发展类型转移具有显著影响, 高水平区域具 有辐射、促进作用,而低水平区域背景具有制约、减缓作用。

(2) 分指标来看,各个分指标综合得分都有不同程度的波动上升,其中文化管理建设增加幅度最小,生态 环境增加幅度最大。各个省份之间海洋资源利用程度水平差异最小, 海洋经济绿色发展综合得分最高, 为海 洋绿色发展提供了物质保障。各个指标综合得分省份排名也不同, 海洋生态环境友好指标中上海和天津最 高; 海洋资源利用程度指标中福建和海南最高; 海洋经济绿色发展指标中上海和广东最高;海洋文化管理建设 中上海和广东最高。

(3) 影响因素,从外部因素来看,政府调控、陆域经济水平和开放程度对海洋绿色发展有正向显著影响, 环境治理有负向显著影响, 就业潜力有正向不显著影响。从内部因素来看, 海洋产业结构、海洋管理和海洋资 源利用都有正向显著影响,海洋科技创新有负向不显著影响。海洋产业结构、科技创新、陆域经济水平、开放 程度等要素通过经济生态化演变机制、投人产出机制、区际转移机制等路径影响海洋绿色发展。

\section{2 建议}

整体上, 在保护生态环境的前提下, 加大政府调控, 扩大开放, 重点发展绿色海洋经济, 改变传统的发展观 念、生产观念和消费观念, 提高经济生态化。调整海洋产业结构, 积极培育海洋战略性新兴产业, 逐步优化海 洋产业结构, 从而提高科技创新投人产出效率。进一步加强海洋文化宣传和海洋管理制度建设, 为海洋绿色 发展提供软实力,最终推动海洋绿色发展空间格局向均衡方向演化。

区域上, 根据海洋绿色发展水平时空分布差异和各个子系统空间演变规律, 给出如下建议: (1)在加大对海 
洋资源有效利用的同时,东北沿海省市应该充分利用振兴东北老工业区基地的国家政策,进一步发展海洋绿 色经济和加强海洋文化制度管理建设,加快产业转型升级。(2)津、河北在努力推进海洋经济绿色发展的同 时,需重点抢抓京津冀协同发展政策,充分利用京津冀资本,合理分配京津冀科学技术和产业,加强省域交流 合作,加大海洋文化传播力度,有效利用 “俱乐部趋同” 效应, 更好的协同京津冀发展。(3)对于东、南沿海省市 海洋绿色发展水平较高的地区, 如: 江浙沪一带, 应充分利用优越的地理位置和丰富的人力资本要素, 优化产 业结构, 大力推动高新技术产业发展, 提高对外开放水平, 更好的发挥其辐射带头作用。江苏应重点发展科技 含量高、引领作用强和经济提升快的海洋项目来提升海洋经济发展, 做好陆海统筹, 利用好长三角经济区区位 优势, 加强对外交流合作; 福建和广东应重点解决生态环境的突出问题以及发挥自己的地域优势进一步扩大 进出口, 提高科技投人产出效率。(4)海南作为国际旅游岛建设区, 需要重点打造低碳经济, 发展旅游服务业, 而广西在维持经济持续向好态势的同时需要突出创新发展,应更好的利用海洋资源, 构建现代化海洋产业体 系, 促进海洋生态文明建设, 加快推进法治海洋建设, 利用海上丝绸之路建设优势。

\section{参考文献 (References) :}

[1] 林香红. 面向 2030: 全球海洋经济发展的影响因素、趋势及对策建议. 太平洋学报, 2020, 28(1): 50-63.

[ 2 ] Liu B Q, Xu M, Wang J, Xie S M. Regional disparities in China's marine economy. Marine Policy, 2017, 82: 1-7.

[ 3 ] Barbier E B, Markandya A. A New Blueprint for a Green Economy. Top Sustainability Books, 1989, 7( 1) :70-76(7).

[ 4 ] Victor P A, Jackson T. A commentary on UNEP's green economy scenarios. Ecological Economics, 2012, 77: 11- 15.

[ 5] 胡鞍钢. 中国: 创新绿色发展. 北京: 中国人民大学出版社, 2012: 56-56.

[ 6 ] 黄跃, 李琳. 中国城市群绿色发展水平综合测度与时空演化. 地理研究, 2017, 36(7): 1309-1322.

[ 7 ] 周峰. 保护海洋生态系统引领海洋绿色发展. 国土资源, 2018, (8) : 6-9.

[ 8 ] Dwaikat L N, Ali K N. The economic benefits of a green building-Evidence from Malaysia. Journal of Building Engineering, 2018, 18: 448-453.

[ 9 ] Rola R. ISO 14001 certification a step ahead towards implementation of green supply chain management practices in chemical industries. Kvant Electron, 2016, 17(19): 399-401.

[10] Barbier E. The Policy Challenge for green economy and Sustainable Development. Natural Resources Forum, 2011, 35(3) :233-245.

[11] Kunanuntakij K, Varabuntoonvit V, Vorayos N, Panjapornpon C Mungcharoen T. Thailand Green GDP assessment based on environmentally extended input-output model. Journal of Cleaner Production, 2017, 167: 970-977.

[12] Li K, Song M. Green development performance in China: a metafrontier non-radial approach. Sustainability, 2016, 8( 3) : 219.

[13] Feng C, Wang M, Liu G C, Huang J B. Green development performance and its influencing factors: a global perspective. Journal of Cleaner Production, 2017, 144: 323-333.

[14] Sun C Z, Tong Y L, Zou W. The evolution and a temporal-spatial difference analysis of green development in China. Sustainable Cities and Society, 2018, $41: 52-61$.

[15] Zhou B, Liu W, Lu W, et al. Application of OECD LSE Framework to Assess Spatial Differences in Rural Green Development in the Arid Shaanxi Province, China. International Journal of Environmental Research and Public Health, 2020, 17(1).

[16] Rüstemoğlu H. Factors affecting Germany's green development over 1990-2015: a comprehensive environmental analysis. Environmental Science and Pollution Research, 2019, 26(7): 6636-6651.

[17] Penz E, Polsa P. How do companies reduce their carbon footprint and how do they communicate these measures to stakeholders? Journal of Cleaner Production, 2018, 195: 1125-1138.

[18] Karani Patrick, Failler Pierre. Comparative coastal and marine tourism, climate change, and the blue economy in African Large Marine Ecosystems. Environmental Development, 2020,36.

[19］张欢，罗畅，成金华，王鸿涛. 湖北省绿色发展水平测度及其空间关系. 经济地理，2016，36(9): 158- 165 .

[20］孙才志, 童艳丽, 刘文新. 中国绿色化发展水平测度及动态演化规律. 经济地理, 2017, 37(2): 15-22.

[21] 李俊杰, 景一佳. 基于 SBM-GIS 的绿色发展效率评价及时空分异研究一一中原城市群为例. 生态经济, 2019, 35(9): 94-101, 107-107.

[22] 郭永杰, 米文宝, 赵荣. 宁夏县域绿色发展水平空间分异及影响因素. 经济地理, 2015, 35(3): 45-51, 8-8.

[23] 程铑, 王晶晶, 王亚平, 任建兰. 中国绿色发展时空演变轨迹与影响机理研究. 地理研究, 2019, 38(11): 2745-2765.

[24] 杜建国, 王玥, 赵爱武. 智慧城市建设对城市绿色发展的影响及作用机制研究. 软科学, 2020, 34(9) : 59-64. 
[25] 孙剑锋, 秦伟山, 孙海燕, 李世泰, 杜岩. 中国沿海城市海洋生态文明建设评价体系与水平测度. 经济地理, 2018, 38(8): 19-28.

[26］苗德霞, 张得银, 于平. 基于生态文明建设的江苏海洋经济高质量发展研究. 海洋经济, 2020, 10(2) : 17-27.

[27］田良, 秦灿. 山东省海洋生态文明建设探索与实践. 海洋开发与管理, 2017, 34( S2) : 9-12.

[28］张莉, 何春林, 乔俊果. 广东省绿色海洋经济发展的效益评价. 太平洋学报, 2008, (8) : 78-87.

[29］贾建琦，赵林. 中国海洋经济绿色包容性的时空分异与影响因素分析. 资源开发与市场, 2019, 35(12): 1491-1496, $1555-1555$.

[30］赵昕, 彭勇, 丁黎黎. 中国海洋绿色经济效率的时空演变及影响因素. 湖南农业大学学报: 社会科学版, 2016, 17(5): 81-89.

[31] 关洪军, 孙珍珍, 高浩楠, 赵爱武. 中国海洋经济绿色全要素生产率时空演化及影响因素分析. 中国海洋大学学报: 社会科学版, 2019, (6) : 40-53.

[32] 丁黎黎, 朱琳, 何广顺. 中国海洋经济绿色全要素生产率测度及影响因素. 中国科技论坛, 2015, (2) : 72-78.

[33] 陈守显. 工程可变模糊集理论与模型—模糊水文水资源学数学基础. 大连理工大学学报, 2005, 45(2): 308-312.

[34] 陈守显. 工程模糊集理论与应用. 北京: 国防工业出版社, 1998.

[35] 王泽宇, 郭萌雨, 孙才志, 李博. 基于可变模糊识别模型的现代海洋产业发展水平评价. 资源科学, 2015, 37(3): 534-545.

[36] 柯丽娜, 王权明, 孙新国, 孙才志, 周惠成, 王方雄. 基于可变模糊识别模型的海水环境质量评价. 生态学报, 2013, 33(6): 1889-1899.

[37] 郭艳花, 佟连军, 梅林. 吉林省限制开发生态区绿色发展水平评价与障碍因素. 生态学报, 2020, 40(7) : 2463-2472.

[38］李效顺, 张绍良, 汪应宏. 中国经济转型阶段建设用地增长极限计量研究. 自然资源学报, 2011, 26(7): 1085- 1095.

[39] 陈海燕. 面板数据模型的检验方法研究 [D]. 天津: 天津大学, 2010.

[40］陆志强, 李吉鹏, 章耕耘, 马丽. 基于可变模糊评价模型的东山湾生态系统健康评价. 生态学报, 2015, 35(14) : 4907-4919.

[41] 王泽宇, 卢函, 孙才志, 韩增林, 孙康, 董晓菲. 中国海洋经济系统稳定性评价与空间分异. 资源科学, 2017, 39(3): 566-576.

[42] 陈守显. 可变模糊聚类及模式识别统一理论与模型. 大连理工大学学报, 2009, 49(2): 307-312.

[43] 王泽宇, 卢雪凤, 孙才志, 韩增林, 董晓菲. 中国海洋经济重心演变及影响因素. 经济地理, 2017, 37( 5) : 12-19.

[44] 王波, 韩立民. 中国海洋产业结构变动对海洋经济增长的影响一一基于沿海 11 省市的面板门槛效应回归分析. 资源科学, 2017, 39(6)： 1182-1193.

[45] 邹玮, 孙才志, 覃雄合. 基于 Bootstrap-DEA 模型环渤海地区海洋经济效率空间演化与影响因素分析. 地理科学, 2017, 37(6)：859-867.

[46] 姜微, 汤旭, 刘俊昌. 南方 13 省份林业产业生态效率时空演变及其影响因素. 生态学报, 2020, 40(16): 5663-5673.

[47] 刘佳, 陆菊, 刘宁. 基于 DEA-Malmquist 模型的中国沿海地区旅游产业效率时空演化、影响因素与形成机理. 资源科学, 2015, 37(12): 2381-2393.

[48] 黄和平, 李亚丽, 王智鹏. 基于 Super-SBM 模型的中国省域城市工业用地生态效率时空演变及影响因素研究. 生态学报, 2020, 40(1) : 100-111. 